\title{
Waiting DAAs list mortality impact in HCV cirrhotic patients
}

\author{
Giovanni Faria SILVA, Vanessa Gutierrez de ANDRADE and Alecsandro MOREIRA
}

Received 13/5/2018 Accepted 30/8/2018

ABSTRACT - Background - The infection for the hepatitis C virus (HCV) is a leading cause of liver-related morbidity and mortality through its evolution to liver cirrhosis, end-stage liver complications and hepatocellular carcinoma. Currently, the new drugs for the HCV infection, based on direct antiviral agents, have changed the outcomes in this setting. Objective - To assess death incidence, during the wait for the treatment with the new drugs, and to analyze which independent variable (age, sex, ascite, HDA, albumin, $\alpha$-fetoprotein, platelets and Meld score) had relation with death. Methods - Prospective study with cirrhotic patients by HCV. Inclusion: cirrhotic patients by hepatic biopsy (METAVIR), clinic or image, detectable RNA (HCV). Exclusion: Other stages of hepatic fibrosis and hepatocellular carcinoma. Descriptive statistic in continue variables. Fisher Exact and Kaplan Meier and Cox Regression Analysis to assess the association of variables studied with death. $P<0.05$. Results - A total of 129 patients were included. Of this, $73 \%$ were men. Mean age was $57.8 \pm 12.1$, albumin of $3.5 \pm 0.6 \mathrm{mg} / \mathrm{dL}$, platelets of $123.4 \pm 59.6$ and Meld score of $10.59 \pm 3.56$. The time of observation was 11.2 \pm 3.26 months, and the number of death $9 / 129(6,9 \%)$. The Kaplan-Meier showed association between death with albumin lower than 2.9 (0.0006), MELD score higher than 15 (0.007) and $\alpha$-fetoprotein higher than $40 \mathrm{ng} / \mathrm{mL}(<0.0001)$. Adjusted Cox Regression Analysis showed that $\alpha$-fetoprotein higher than $40 \mathrm{ng} / \mathrm{ml}$ could be considered an independent risk for death. Conclusion - We conclude that, patients with advanced cirrhosis should be prioritized for treatment with direct antiviral agents.

HEADINGS - Hepacivirus. Liver cirrhosis, drug therapy. Liver cirrhosis, mortality.

\section{INTRODUCTION}

The infection for the hepatitis $\mathrm{C}$ virus $(\mathrm{HCV})$ is a leading cause of liver-related morbidity and mortality through its evolution to liver cirrhosis, end-stage liver complications and hepatocellular carcinoma. Currently, the new drugs for the HCV infection, based on direct antiviral agents (DAAs), have changed the outcomes in this setting. These drugs have been used safely and effectively in cirrhotic patients, including decompensated cirrhosis which is responsible for significant morbidity and mortality, along with healthcare costs ${ }^{(1)}$. It took a long time for DAA therapy to become available in Brazil, leaving patients (including cirrhotics) with no effective treatment to their condition; For this reason, it was possible to observe the disease's natural progression in many patients. The aim of this study is to evaluate mortality rate in cirrhotic patients while awaiting the DAAs.

\section{METHODS}

This was a prospective study of HCV-RNA positive patients with liver cirrhosis, admitted to the University Hospital of Botucatu (Botucatu School of Medicine, São Paulo State University). Data collection was undertaken between April 2015 and May 2016, and was approved by Ethics Committee of this Hospital (4378-2012); all patients' data were anonymized. A diagnosis of cirrhosis was made if the patient had a positive liver biopsy on record, or if they had clinical features of cirrhosis along with any of the following: evidence of portal hypertension, ascites, encephalopathy or signs of liver cirrhosis on ultrasound, CT scan or liver elastography examination. Exclusion criteria for this study were: Active hepatocellular carcinoma at baseline, and contraindication to DAAs therapy. Data were collected and recorded prospectively. Demographic data collected included: gender, age, viral genotype, platelet count, liver function tests (albumin, bilirubin and INR), MELD score and alpha-fetoprotein. We collected and recorded the treatment's experience and ascites. The history of bleeding from varices was also registered. Outcomes of interest were time of death, or beginning of treatment with DAAs. Data was recorded and analyzed using SPSS 17.0, Chicago, IL, USA. Nominal variables are presented in absolute and relative frequencies. For continuous variables, descriptive statistics are presented as mean and standard deviation, with minimum and maximum values. The associations between selected factors and death were compared using the Fisher's exact test or Chi-squared test for association or trend, as appropriate. A Kaplan-Meier survival analysis was performed to evaluate the influence of the variables on outcomes. Cox's regression analysis was also performed. The level of statistical significance for all tests was set at $P=0.05$.

Declared conflict of interest of all authors: none

Disclosure of funding: supported by Merck Sharp \& Dohme

Universidade Estadual Paulista (UNESP), Faculdade de Medicina, Departamento de Clínica Médica, Botucatu, SP, Brasil.

Corresponding author: Giovanni Faria Silva. Orcid: https://orcid.org/0000-0001-6129-7045. E-mail: giovanni@fmb.unesp.br 


\section{RESULTS}

Demographics: Of 214 patients evaluated during the study period, 129 patients met the diagnostic criteria for cirrhosis (therapy with DAAs was also indicated): $73 \%$ male (94/129), the mean patient age of $57.8 \pm 12.1 \mathrm{yrs}$, mean serum albumin of $3.5 \pm 0.6 \mathrm{mg} /$ $\mathrm{dL}$, mean platelet count of $123.4 \pm 59$ and mean MELD score of $10.59 \pm 3.56$. The mean time follow up was $11.2 \pm 3.26$ months. The number of deaths was $9 / 129(6.9 \%)$, these patients had lower levels of serum albumin and bilirubin associated with a higher MELD score than the survivors (TABLE 1). We observed no statistically significant differences among death and gender; genotype 1 and 3; history of ascites or bleeding varices. However, there were clear associations between death and: albumin levels lower than 3.5 $\mathrm{mg} / \mathrm{dL}(0.03)$, or lower than $2.9 \mathrm{mg} / \mathrm{dL}(0.006)$, when comparing naïve patients with experienced ones (0.0002), and also between death and MELD scores higher than 15 (0.017). Analysis of the Kaplan-Meier survival curve showed a significant association between death in naive patients (0.0005), albumin lower than 2.9 (0.0006), MELD score higher than 15 (0.007) and $\alpha$-fetoprotein higher than $40 \mathrm{ng} / \mathrm{mL}(<0.0001)$. No significant differences were found regarding bilirubin, past of ascites or bleeding varices, as well as Inr. Adjusted Cox Regression Analysis showed that only levels of $\alpha$-fetoprotein higher than $40 \mathrm{ng} / \mathrm{mL}$ could be considered an independent risk for death.

TABLE 1. Collection parameters and comparison with survivor population.

\begin{tabular}{|c|c|c|c|c|}
\hline Parameter & $\begin{array}{l}\text { Mean avarage } \\
\text { baseline } \\
\text { (All population) }\end{array}$ & Variables & Censored & Death \\
\hline Gender & $\begin{array}{c}\text { Male: } 73 \%(94 / 129) \\
\text { Female: } 27 \% \\
(35 / 129)\end{array}$ & & & \\
\hline Age (years) & $57.8 \pm 12.1$ & $\begin{array}{c}\text { Age } \\
\text { (years) }\end{array}$ & $57.7 \pm 11.8$ & $58.4 \pm 16.3$ \\
\hline $\begin{array}{l}\text { Albumin } \\
(\mathrm{mg} / \mathrm{dL})\end{array}$ & $3.5 \pm 0.6$ & $\begin{array}{l}\text { Albumin } \\
(\mathrm{mg} / \mathrm{dl})\end{array}$ & $3.6 \pm 0.5$ & $2.9 \pm 0.6$ \\
\hline $\begin{array}{l}\text { Platelet } \\
\text { Count }\end{array}$ & $123.4 \pm 59,6$ & Bilirrubin & $1.4 \pm 1.2$ & $3.7 \pm 5.0$ \\
\hline \multirow[t]{2}{*}{$\begin{array}{l}\text { MELD } \\
\text { Score }\end{array}$} & $10.59 \pm 3.56$ & $\begin{array}{l}\text { MELD } \\
\text { score }\end{array}$ & $10.3 \pm 3.2$ & $13.7 \pm 5.5$ \\
\hline & & Inr & $1.21 \pm 0.1$ & $1.36 \pm 0.3$ \\
\hline
\end{tabular}

MELD: Model for End-Stage Liver Disease; Inr: International Normalized Ratio.

\section{DISCUSSION}

The virus of hepatitis $\mathrm{C}$ affects around 200 million people worldwide, and is the leading cause of cirrhosis, hepatocellular carcinoma, and liver transplantation in western countries ${ }^{(2)}$. HCVrelated cirrhosis has a $1 \%-5 \%$ annual risk of leading to liver cancer and 3\%-6\% risk of clinical decompensation, after which, patients have a 4\%-67\% chance of dying ${ }^{(3)}$. During the interferon-based therapy, Sustained Virologic Response (SVR) was around 40\%$80 \%$, but in cirrhotics it was approximately $20 \% \%^{(4)}$. However, its use in patients with decompensated cirrhosis was not permitted, mainly due to the risk of infection and death ${ }^{(5)}$. Nowadays, the safety and efficacy of DAAs has enabled the treatment of cirrhosis, including decompensated cirrhosis. For this reason, patients with advanced liver disease have been included in the waiting list for DAA treatment. Recently, D'Amico et al. ${ }^{(6)}$ proposed a new classification for cirrhosis, based on clinical criteria, and their prognosis. In this classification, there are 4 stages: 1 (no ascites, no varices); 2 (varices, no ascites); 3 (ascites \pm varices) and 4 (variceal bleeding \pm ascites). The estimated mortality rates per year are $1 \%$, $3.4 \%, 20 \%$ and $57 \%$, respectively ${ }^{(6)}$. More recently, other authors proposed a 5th stage, due to infection and renal failure, with an increase on mortality rate from 1 year to $67 \%{ }^{(7)}$. Recently published data showed that the 5 year cumulative incidence of liver-related mortality in decompensated cirrhotics was $61.3 \%{ }^{(8)}$. Patients studied in our work were predominantly male, mean age of 57.8 years old. The mortality rate at the mean time of 11.2 months was $6.9 \%$. Although we did not use the previous classification described, we observed in our study patients with advanced liver disease, with previous ascites $(27.9 \%)$ and in $9 \%$ past of variceal bleeding. On the other hand, $41 \%$ them had platelets less than $100.000 / \mathrm{mm}^{3}$; $\alpha$-fetoprotein above 20 and $40 \mathrm{ng} / \mathrm{dL}$ were observed in $21 \%$ and $11 \%$ respectively, and also albumin less than 3.5 and 2.9 were seen in $43 \%$ and $17 \%$, respectively. The analysis showed that in naive patients, albumin less than 3.5 and $2.9 \mathrm{mg} / \mathrm{dL}$, MELD score above 15 and $\alpha$-fetoprotein above 20 and $40 \mathrm{ng} / \mathrm{dL}$ were associated with death. Cox regression analysis showed that the only independent factor associated with death was $\alpha$-fetoprotein greater than $40 \mathrm{ng} /$ $\mathrm{dL}$. The public health system in Brazil began to offer treatments with DAAs in December 2015. Before that we could not offered any treatment for 1.5 years, and therefore, we were able to observe the natural evolution of cirrhosis.

\section{CONCLUSION}

With this study we concluded that, patients with advanced liver disease should be prioritized for treatment with DAAs.

\section{ACKNOWLEDGEMENTS}

Study Group of HCV: Adriane Fernandes, Liciana Vaz Silveira, Fábio da Silva Yamashiro, Cássio Vieira Oliveira, Walnei Fernandes Barbosa, Vanessa Nogueira da Silva Paixão, Letícia Lastória Kurozawa, Flávia Chiacchio, Rejane Maria Tommasini Grotto, Maria Inês de Moura Campos Pardini. All of them performed the reasearch.

\section{Authors' contribution}

Silva GF: designed the study, wrote the paper and revised the manuscript for final submission. Andrade VG and Moreira A: performed the research. 
Silva GF, Andrade VG, Moreira A. Impacto da lista de espera para AADs em pacientes cirróticos por VHC. Arq Gastroenterol. 2018;55(4):343-5.

RESUMO - Contexto - A infecção pelo vírus da hepatite C (VHC) é uma das principais causas de morbidade e mortalidade relacionada ao fígado, através de sua evolução para cirrose hepática, complicações hepáticas em estágio terminal e carcinoma hepatocelular. Atualmente, os novos fármacos para a infecção pelo VHC, baseados nos novos antivirais de ação direta (AADs), modificaram os resultados nesse cenário. Objetivo - Avaliar a incidência de morte, durante a espera pelo tratamento com as novas drogas, e analisar quais variáveis independentes (idade, sexo, ascite, HDA, albumina, $\alpha$-fetoproteína, plaquetas e escore de MELD) tiveram relação com o óbito. Métodos - Estudo prospectivo com pacientes cirróticos pelo VHC. Inclusão: pacientes cirróticos por biópsia hepática (METAVIR), clínica ou imagem, RNA detectável (VHC). Exclusão: Outras fases de fibrose hepática e carcinoma hepatocelular. Estatística descritiva em variáveis contínuas. Exato de Fisher e Kaplan Meier e Análise de Regressão de Cox para avaliar a associação das variáveis estudadas com o óbito. $P<0,05$. Resultados - Um total de 129 pacientes foram incluídos. Destes, $73 \%$ eram homens. A idade média foi de $57,8 \pm 12,1$, a albumina de $3,5 \pm 0,6 \mathrm{mg} / \mathrm{dL}$, as plaquetas de 123,4 $\pm 59,6$ e o escore de MELD de 10,59 $\pm 3,56$. O tempo de observação foi de $11,2 \pm 3,26$ meses e o número de mortes $9 / 129(6,9 \%)$. O Kaplan-Meier mostrou associação entre o óbito com albumina menor que 2,9 (0,0006), escore MELD maior que $15(0,007)$ e $\alpha$-fetoproteína maior que $40 \mathrm{ng} / \mathrm{mL}(<0,0001)$. A análise de regressão de Cox ajustada mostrou que $\alpha$-fetoproteína maior que $40 \mathrm{ng} / \mathrm{mL}$ poderia ser considerada um risco independente para morte. Conclusão - Concluímos que pacientes com cirrose avançada devem ser priorizados para tratamento com AADs.

DESCRITORES - Hepacivirus. Cirrose hepática, tratamento farmacológico. Liver cirrhosis, mortalidade.

\section{REFERENCES}

1. Volk ML, Piette JD, Singal AS, Lok AS. Chronic disease management for patients with cirrhosis. Gastroenterology. 2010;139:14-16.

2. Ansaldi F, Orsi A, Sticchi L, Bruzzone B, Icardi G. Hepatitis C virus in the new era: Perspectives in epidemiology, prevention, diagnostics and predictors of response to therapy. World J Gastroenterol. 2014;20:9633-52.

3. Tsochatzis EA, Bosch J, Burroughs AK. Liver cirrhosis. Lancet. 2014;383:1749-61.

4. Silva GF, Villela-Nogueira CA, Mello CEB, Soares EC, Coelho HSM, Ferreira $\mathrm{PR}$, et al. Peginterferon plus ribavirin and sustained virological response rate in HCV-related advanced fibrosis: a real life study. Braz J Infect Dis. 2014;18:48-52.

5. Iacobellis A, Siciliano M, Perri F, Annicchiarico BE, Leandro G, Caruso N, et al. Peginterferon alfa-2b and ribavirin in patients with hepatitis $\mathrm{C}$ virus and decompensated cirrhosis: a controlled study. J Hepatol. 2007;46:206-12.
6. D'Amico G, Garcia-Tsao G, Pagliaro L. Natural history and prognostic indicators of survival in cirrhosis: a systematic review of 118 studies. J Hepatol. 2006; 44:217-31.

7. Arvaniti V, D’Amico G, Fede G, Manousou P, Tsochatzis E, Pleguezuelo M, et al. Infections in patients with cirrhosis increase mortality four-fold and should be used in determining prognosis. Gastroenterology. 2010;139:1246-56.

8. McDonald SA, Innes HA, Aspinall E, Hayes PC, Alavi M, Valerio H, et al. Prognosis of 1169 hepatitis $\mathrm{C}$ chronically infected patients with decompensated cirrhosis in the predirect-acting antiviral era. J Viral Hepat. 2017 Apr;24(4): 295-303. 